\title{
molecules
}

ISSN 1420-3049

(C) 2008 by MDPI

www.mdpi.org/molecules

Full Paper

\section{Effects of Leucine-enkephalin on Catalase Activity and Hydrogen Peroxide Levels in the Haemolymph of the Pacific Oyster (Crassostrea gigas)}

\section{Dong-wu Liu *, Zhi-wei Chen and Hong-zhi Xu}

Analysis and Testing Center, Shandong University of Technology, 255049, Zibo, Shandong, P.R. China

* Author to whom correspondence should be addressed; E-mail: liudongwu@sdut.edu.cn

Received: 21 March 2008; in revised form: 6 April 2008 / Accepted: 7 April 2008 / Published: 15 April 2008

\begin{abstract}
The nervous and immune systems of invertebrates can exchange information through neuropeptides. Furthermore, some opioid peptides can function as endogenous immune system messengers and participate in the regulation of the immune responses. The present study was designed to investigate the effects of leucine-enkephalin (L-ENK) on the activity of catalase (CAT) and hydrogen peroxide $\left(\mathrm{H}_{2} \mathrm{O}_{2}\right)$ content in the haemolymph of the Pacific Oyster (Crassostrea gigas). The CAT activity and $\mathrm{H}_{2} \mathrm{O}_{2}$ content were investigated after the haemolymph of the species was exposed to 1,5 , and $50 \mu \mathrm{g} / \mathrm{mL}$ of LENK. The results indicate that the intracellular and extracellular CAT activity was increased with increasing concentration of L-ENK, while the intracellular and extracellular $\mathrm{H}_{2} \mathrm{O}_{2}$ content was decreased with increasing concentration of L-ENK. L-ENK may regulate the intracellular and extracellular CAT activity and $\mathrm{H}_{2} \mathrm{O}_{2}$ content via binding with opioid neuropeptide receptors on immunocytes of the oysters. The data strongly suggests an involvement of opioid peptides in the regulation of the antioxidant defence systems of Crassostrea gigas.
\end{abstract}

Keywords: Crassostrea gigas; leucine-enkephalin; haemolymph; catalase; hydrogen peroxide. 


\section{Introduction}

Studies on the immunity of bivalve molluscs are becoming increasingly numerous as a result of the importance of these models from ecological and economic points of view [1]. Furthermore, the bivalve molluscs represent an ideal alternative to vertebrates, because they mirror in a simplified way the immuno-neuroendocrine activities in vertebrate cells. Haemocytes play pivotal roles in internal defence in molluscs that lack acquired immunity. Recognition, phagocytosis and killing of viruses and bacteria are one of the most important functions of invertebrate immunocytes [2]. Reactive oxygen species (ROS), such as superoxide ions, hypochlorous acid, and hydrogen peroxide $\left(\mathrm{H}_{2} \mathrm{O}_{2}\right)$, are produced to kill phagocytosed organisms. However, if these noxious oxygen derivatives are not controlled by antioxidant defence systems, oxidative stress occurs [3]. Oxidative stress has been related to many pathophysiological states, e.g. ischemia-reperfusion injury, hyperoxia, hypoxia, iron overload and intoxication [4-6].

The nervous and immune systems of invertebrates can exchange information through neuropeptides [7-9]. Furthermore, it appears that some opioid peptides can function as endogenous messengers of the immune system, and likely participate in the regulation of the immune response [1013]. There is evidence for the presence of opioids in lymphoid cells and for their release into the circulation in response to stress, and the involvement of endogenous opioid peptides in the mobilization, directed movement, and adherence of immunoreactive cells and in several related immune processes has been shown [14-17]. Moreover, endogenous opioid peptides in invertebrates can induce chemotaxis, and some mammalian-like cytokines, such as interleukin-1, interleukin-6 and tumor necrosis factor- $\alpha$, are released [18-19].

Since the roles played by endogenous opioids and opioid receptors in neuroendocrine control mechanisms of invertebrates closely parallel those in vertebrates [20-22], the question arises whether the endogenous opioids affect antioxidant defence systems of the Pacific Oyster (Crassostrea gigas). The aims of the present study were to investigate the effects of leucine-enkephalin (L-ENK) on the activity of catalase (CAT) and $\mathrm{H}_{2} \mathrm{O}_{2}$ content in the hemolymph of the Pacific Oyster.

\section{Results and Discussion}

The internal defense system of bivalves consists of both humoral and cellular immunity. Since they do not possess immunoglobulins, bivalves have developed unique modalities to detect and respond to bacterial, fungal, and viral pathogens. Recognition, phagocytosis and killing of viruses and bacteria are one of the most important functions of invertebrate immunocytes [2]. To kill phagocytosed organisms, ROS are produced. However, oxidative stress occurs if these noxious oxygen derivatives are not controlled by antioxidant defence systems [3]. CAT is an antioxidant enzyme that degrades the hydrogen peroxide $\left(\mathrm{H}_{2} \mathrm{O}_{2}\right)$. In order to determine the influence of L-ENK on CAT activity and $\mathrm{H}_{2} \mathrm{O}_{2}$ content, samples of the haemocyte lysate supernatant (HLS) and supernatant prepared from oysters were separately exposed with 1,5 and $50 \mu \mathrm{g} / \mathrm{mL}$ of L-ENK. The results showed that the intracellular and extracellular CAT activity increased with the increase of L-ENK concentration (Fig 1.A), while the intracellular and extracellular $\mathrm{H}_{2} \mathrm{O}_{2}$ content was decreased with the increase of L-ENK concentration (Fig 1. B). The intracellular and extracellular CAT activity of 1,5 and $50 \mu \mathrm{g} / \mathrm{mL}$ group 
was higher than that of control group $(\mathrm{P}<0.01$ at 5 and $50 \mu \mathrm{g} / \mathrm{mL}$, and $\mathrm{P}<0.05$ at $1 \mu \mathrm{g} / \mathrm{mL}$, Figure 1.A). However, the intracellular and extracellular $\mathrm{H}_{2} \mathrm{O}_{2}$ content of 1,5 and $50 \mu \mathrm{g} / \mathrm{mL}$ group was lower than that of control group $(\mathrm{P}<0.01$, Figure 1.B). Thus L-ENK may be a good agent to maintain intracellular and extracellular redox balance of the haemolymph of the oysters.

Figure 1. Extracellular and intracellular CAT activity and $\mathrm{H}_{2} \mathrm{O}_{2}$ content of haemolymph exposed to different concentrations of L-ENK. (A) Extracellular and intracellular CAT activity of haemolymph exposed to different concentrations of L-ENK. (B) Extracellular and intracellular $\mathrm{H}_{2} \mathrm{O}_{2}$ content of haemolymph exposed to different concentrations of LENK. ${ }^{a} \mathrm{P}<0.05$ compared with control group, ${ }^{\mathrm{b}} \mathrm{P}<0.01$ compared with control group. The error bars represent the SD.

(A) CAT activity in hemolymph

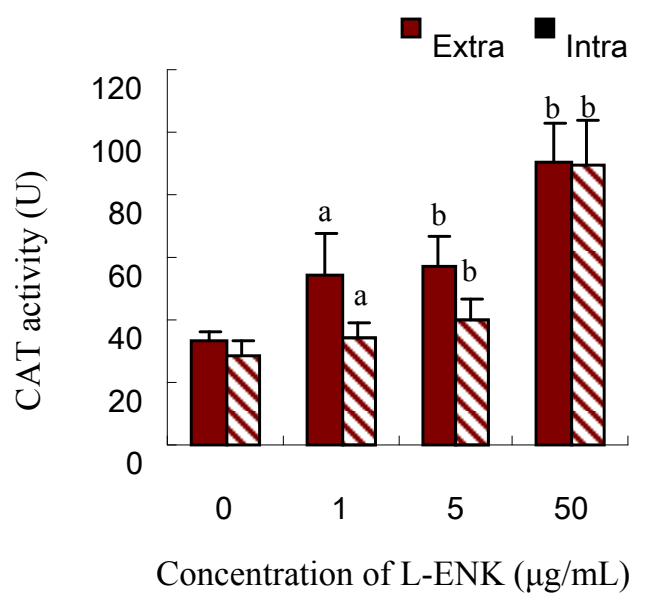

(B) $\mathrm{H}_{2} \mathrm{O}_{2}$ content in haemolymph
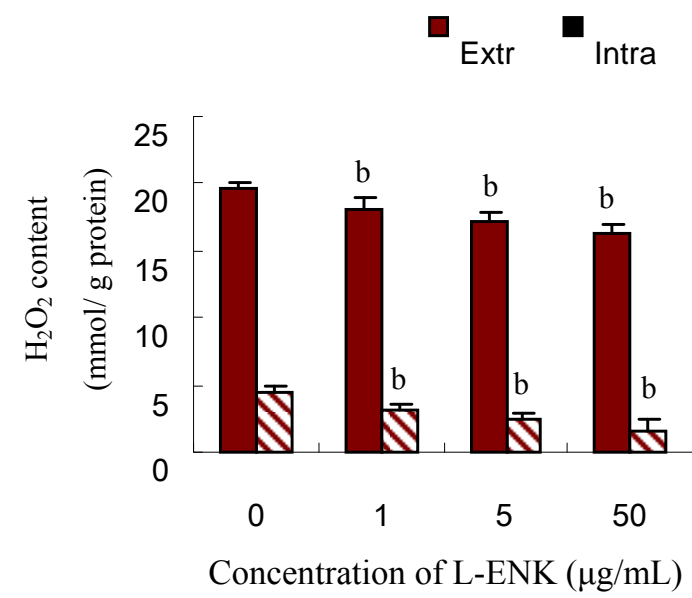

Neuropeptides can function as messengers between the neuroendocrine and the immune systems. Some reports have demonstrated by immunohistological methods the occurrence of mammalian neuropeptide-like immunoreactivity in various invertebrate nervous systems [23-26]. It has been found that opioid peptides can stimulate cytokine release and immunocyte chemotaxis, and induce conformational changes in immunocytes. In particular, Methionine-enkephalin (M-ENK) and D'Ala2Met5-enkephalinamide are potent mediators of immunocyte conformational changes in both invertebrates and mammals [8]. The present report demonstrates that L-ENK participates in the immune responses of the Pacific Oyster (Crassostrea gigas). It has been demonstrated that M-ENK enhances NO production in phorbol myristate acetate-stimulated rat peritoneal macrophages mainly through $\delta_{1}$ opioid receptor [27]. In our previous report, we found L-ENK and delta receptors on immunocytes, and L-ENK increased CAT activity and glutathione content in the hemolymph of the scallop Chlamys farreri [28]. Thus we surmise that L-ENK may bind with receptors on immunocytes and results in the increase of CAT activity and decrease of $\mathrm{H}_{2} \mathrm{O}_{2}$ content in the hemolymph of the Pacific Oyster. Overall, the data strongly suggests an involvement of opioid peptides in the regulation of the antioxidant defence systems of this species. 


\section{Conclusions}

L-ENK can regulate the intracellular and extracellular CAT activity and $\mathrm{H}_{2} \mathrm{O}_{2}$ content in the hemolymph of the Pacific Oyster (Crassostrea gigas). The intracellular and extracellular CAT activity was increased with increasing concentration of L-ENK, while the intracellular and extracellular $\mathrm{H}_{2} \mathrm{O}_{2}$ content was decreased with increasing concentration of L-ENK. The data strongly suggests an involvement of opioid peptides in the regulation of the antioxidant defence systems of the Pacific Oyster.

\section{Experimental}

\section{Experimental Animals}

A batch of apparently healthy Pacific Oyster (Crassostrea gigas) was purchased from a commercial farm in Zibo, China. They were acclimated in aerated seawater in $120 \mathrm{~L}$ glass containers held at $21^{\circ} \mathrm{C}$ for at least three days prior to each experiment. Stocking densities were generally maintained at 20 oysters per container and artificial feed was given twice a day.

\section{Preparation of Haemocytes and Haemocyte Lysate Supernatant}

A haemolymph sample (approximately $10 \mathrm{~mL}$ ) was drawn from the adductor muscle of 10 oysters with a 25-gauge hypodermic needle. L-ENK (purchased from Sigma Co, USA) was added into the haemolymph at three different concentrations $(1,5$, and $50 \mu \mathrm{g} / \mathrm{mL})$, while the control group did not receive any L-ENK $(0 \mu \mathrm{g} / \mathrm{mL})$. Following incubation at room temperature for $1 \mathrm{~h}$, the haemolymph were centrifuged at $3000 \mathrm{rpm}$ for $10 \mathrm{~min}$. According to a protocol described by Sung et al. [29], the supernatants were collected in order to determine the extracellular enzymatic activity, and the cell pellets were used in preparing the haemocyte lysate supernatant (HLS) which was used to determine the intracellular enzymatic activity. HLS was prepared according to procedures modified by Sung et al. [30]. Briefly, cell pellets were resuspended in diluted water, and then homogenized with a sonicator equipped with a microtip and centrifuged at $6000 \mathrm{rpm}$ for $10 \mathrm{~min}$ at $4{ }^{\circ} \mathrm{C}$.

\section{Assays of CAT Activity and $\mathrm{H}_{2} \mathrm{O}_{2}$ Content}

The CAT activity in HLS and supernatant were separately determined according to procedures described by Marks and Fox [31]. The $\mathrm{H}_{2} \mathrm{O}_{2}$ content in the resultant HLS and supernatant were determined according to procedures described by Góth [32].

\section{Statistics}

Data are expressed as mean \pm SD. Statistical analysis was performed by One-way analysis of variance (ANOVA) followed with comparison test. $\mathrm{P}<0.05$ were considered significant and $\mathrm{P}<0.01$ were considered very significant. The protein concentration of the HLS and supernatant was 
determined according to procedures described by Lowry et al. [33], using bovine serum albumin as a standard.

\section{Acknowledgments}

This work was supported by the Natural Science Foundation for Outstanding Young Scholars of Shandong Province, P.R. China (Grant No. 2007BS06021).

\section{References}

1. Peteiro, L.G.; Labarta, U.; Fernandez-Reiriz, M.J. Variability in biochemical components of the mussel (Mytilus galloprovincialis) cultured after Prestige oil spill. Comp. Biochem. Physiol. C Toxicol. Pharmacol. 2007, 145, 588-594.

2. Ottaviani, E.; Franchini, A.; Fontanili, P. The presence of immunoreactive vertebrate bioactive peptide substances in hemocytes of the freshwater snail Viviparus ater (Gastropoda, Prosobranchia). Cell. Mol. Neurobiol. 1992, 12, 455-462.

3. Sies, H. Oxidative stress: Introductory remarks. In: Oxidative Stress; Sies, H.; Ed.; Academic Press: London and Harcourt Brace Jovanovich Publishers: New York, 1985; pp. 1-8.

4. Di Giulio, R.T.; Washburn, P.C.; Wenning, R.J.; Winston, G.W.; Jewell, C.S. Biochemical responses in aquatic animals: a review of determinants of oxidative stress. Environ. Toxicol. Chem. 1989, 8, 1103-1123.

5. Staniek, K.; Nohl H. $\mathrm{H}(2) \mathrm{O}(2)$ detection from intact mitochondria as a measure for one-electron reduction of dioxygen requires a non-invasive assay system. Biochim. Biophys. Acta. 1999, 1413, 70-80.

6. Nohl, H.; Koltover, V.; Stolze, K. Ischemia/reperfusion impairs mitochondrial energy conservation and triggers O2.- release as a byproduct of respiration. Free Rad. Res. Commun. 1993, 18, 127-137.

7. Stefano, G.B.; Shipp, M.A.; Scharrer, B. A possible immunoregulatory function for [Met]enkephalin-Arg6-Phe7 involving human and invertebrate granulocytes. J. Neuroimmunol. 1991, 31, 97-103.

8. Stefano, G.B.; Scharrer, B.; Smith, E.M.; Hughes, T.K.Jr.; Magazine, H.I.; Bilfinger, T.V.; Hartman, A.R.; Fricchione, G.L.; Liu, Y.; Makman, M.H. Opioid and opiate immunoregulatory processes. Crit. Rev. Immunol. 1996, 16, 109-144.

9. Stefano, G.B.; Salzet, B.; Fricchione, G.L. Enkelytin and opioid peptide association in invertebrates and vertebrates: immune activation and pain. Immunol. Today 1998, 19, 265-268.

10. Salzet, M.; Stefano, G.B. Invertebrate proenkephalin: delta opioid binding sites in leech ganglia and immunocytes. Brain Res. 1997, 768, 224-232.

11. Breslin, M.B.; Lindberg, I.; Benjannet, S.; Mathis, J.P.; Lazure, C.; Seidah, N.G. Differential processing of proenkephalin by prohormone convertases 1(3) and 2 and furin. J. Biol. Chem. 1993, 268, 27084-27093.

12. Isaac, R.; Schoofs, L.; Williams, T.A.; Veelaert, D.; Sajid, M.; Corvol, P.; Coates, D. A novel peptide-processing activity of insect peptidyl-dipeptidase A (angiotensin I-converting enzyme): 
the hydrolysis of lysyl-arginine and arginyl-arginine from the C-terminus of an insect prohormone peptide. Biochem. J. 1998, 330, 61-65.

13. Stefano, G.B.; Salzet-Raveillon, B.; Salzet, M. Mytilus edulis hemolymph contain prodynorphin. Immunol. Lett. 1998, 63, 33-39.

14. Hughes, T.K.Jr.; Smith, E.M.; Barnett, J.A.; Charles, R.; Stefano, G.B. Lipopolysaccharide and opioids activate distinct populations of Mytilus edulis immunocytes. Cell Tissue. Res. 1991, 264, 317-320.

15. Stefano, G.B.; Leung, M.K.; Bilfinger, T.V.; Scharrer, B. Effect of prolonged exposure to morphine on responsiveness of human and invertebrate immunocytes to stimulatory molecules. $J$. Neuroimmunol. 1995, 63, 175-181.

16. Stefano, G.B.; Cadet, P.; Dokun, A.; Scharrer, B. A neuroimmunoregulatory-like mechanism responding to stress in the marine bivalve Mytilus edulis. Brain Behav. Immun. 1990, 4, 323-329.

17. Stefano, G.B.; Smith, E.M.; Cadet, P.; Hughes, T.K.Jr. HIV gp120 alteration of DAMA and IL-1 alpha induced chemotaxic responses in human and invertebrate immunocytes. J. Neuroimmunol. 1993, 43, 177-184.

18. Stefano, G.B.; Smith, E.M.; Hughes, T.K. Opioid induction of immunoreactive interleukin-1 in Mytilus edulis and human immunocytes: an interleukin-1-like substance in invertebrate neural tissue. J. Neuroimmunol. 1991, 32, 29-34.

19. Osman, A.M.; Gomma, M.; Saad, A.H. A possible role for an enkephalinergic system in the internal defense mechanism of Biomphalaria alexandrina exposed to Schistosoma mansoni. $J$. Egypt. Soc. Parasitol. 2003, 33, 841-861.

20. Leung, M.K.; Stefano, G.B. Comparative neurobiology of opioids in invertebrates with special attention to senescent alterations. Prog. Neurobiol. 1987, 28, 131-159.

21. Scharrer, B. Insects as models in neuroendocrine research. Annu. Rev. Entomol. 1987, 32, 1-16.

22. Scharrer, B. Neurosecretion: beginnings and new directions in neuropeptide research. Annu. Rev. Neurosci. 1987, 10, 1-17.

23. Andersen, A.C.; L'Hermite, A.; Ferrand, R.; Dubois, M.P. Immunohistological detection of methionine-enkephalin-like and endorphin-like material in the digestive tract and in the nervous system of the mussel: Mytilus edulis L. Gen. Comp. Endocrinol. 1986, 62, 111-119.

24. Marchand, C.R.; Dubois, M.P. Immunocytochemical detection of substances related to methionine enkephalin in the tentacles and food of the snail (Helix aspersa). C.R. Seances Soc. Biol. Fil. 1986, 180, 184-189.

25. Carpenter, D.O.; Kemenes, G.; Elekes, K.; Leung, M.; Stefano, G.; Rózsa, K.S.; Salánki, J. Opioid peptides in the nervous system of Aplysia: a combined biochemical, immunocytochemical, and electrophysiological study. Cell. Mol. Neurobiol. 1995, 15, 239-256.

26. Zhong, F.; Li, X.Y.; Yang, S.L.; Stefano, G.B.; Fimiani, C.; Bilfinger, T.V. Methionineenkephalin stimulates interleukin-6 mRNA expression: human plasma levels in coronary artery bypass grafting. Int. J. Cardiol. 1998, 64, S53-59.

27. Vujić, V.; Stanojević, S.; Dimitrijević, M. Methionine-enkephalin stimulates hydrogen peroxide and nitric oxide production in rat peritoneal macrophages: interaction of mu, delta and kappa opioid receptors. Neuroimmunomodulation 2004, 11, 392-403. 
28. Liu, D.W. Effects of Leucine-enkephalin on catalase activity and glutathione level in haemolymph of the scallop Chlamys farreri. Pept. Res.Therapeut. 2008, 14, 16-20.

29. Sung, H.H.; Huang, Y.T.; Hsiao, L.T. Phenoloxidase activity of Macrobrachim rosenbergii after challenge with two pathogens: Aeromonas veronii and Lactococcus garvieae. Fish Pathol. 2004, $39,1-8$.

30. Sung, H.H.; Chang, H.J.; Her, C.H.; Chang, J.C.; Song, Y.L. Phenoloxidase activity of hemocytes derived from Penaeus monodon and Macrobrachium rosenbergii. J. Invertebr. Pathol. 1998, 71, 26-33.

31. Marks, G.W.; Fox, D.L. The inactivation of mussel catalase by oxygen. J. Biol. Chem. 1933, 103, 269-283.

32. Góth, L. A simple method for determination of serum catalase activity and revision of reference range. Clin. Chim. Acta 1991, 196, 143-52.

33. Lowry, O.H.; Rosebrough, N.J.; Farr, A.L.; Randall, R.J. Protein measurement with the Folin phenol reagent. J. Biol. Chem. 1951, 193, 265-275.

Sample Availability: Contact the author.

(C) 2008 by MDPI (http://www.mdpi.org). Reproduction is permitted for noncommercial purposes. 